\title{
PERILAKU KEWIRAUSAHAAN PENGRAJIN GERABAH DI KECAMATAN BESUK KABUPATEN PROBOLINGGO
}

\author{
Aris Egayanti ${ }^{1}$, Sukidin ${ }^{1}$, Hety Mustika Ani ${ }^{1}$ \\ ${ }^{1}$ Program Studi Pendidikan, Fakultas Keguruan dan Ilmu Pendidikan, Universitas Jember \\ e-mail:skdn2016@yahoo.com
}

\begin{abstract}
Abstrak
Penelitian ini dilakukan untuk mendeskripsikan perilaku kewirausahaan Pengrajin gerabah di Kecamatan Besuk Kabupaten Probolinggo. Teknik penentuan subjek penelitian dalam penelitian ini menggunakan metode snowball yaitu Pengrajin gerabah di Kecamatan Besuk Kabupaten Probolinggo. Pengumpulan data dalam penelitian ini menggunakan metode wawancara mendalam, observasi atau pengamatan, dan dokumen. Analisis data yang digunakan yaitu reduksi data, penyajian (display) data, verifikasi atau kesimpulan. Berdasarkan hasil penelitian, bahwa pengrajin gerabah menerapkan perilaku kewirausahaan dalam menjalankan usaha gerabah untuk bertahan dan berkembang ditengah persaingan pengrajin gerabah lainnya. Terdapat tiga perilaku kewirausahaan yang dilakukan pengrajin gerabah yaitu: kerja keras, kreativitas dan daya inovatif. Kerja keras yang dilakukan pengrajin gerabah yaitu menjalankan usaha gerabah dengan penuh ketelatenan dalam mengerjakan setiap detail gerabah yang diproduksi serta intensitas waktu kerja yang digunakan dalam rentang waktu relatif lama, semakin lama waktu kerja maka semakin banyak pula jumlah gerabah yang dihasilkan. Hal ini berpengaruh terhadap pencapaian omset yang mereka dapatkan setiap bulan dari hasil penjualan gerabah. Kreativitas yang dilakukan pengrajin gerabah yaitu bagaimana mereka menganalisis segmentasi pasar dan jenis gerabah yang dominan diperlukan oleh masyarakat pada umumnya sehingga pasar bisa open terhadap produk gerabah yang mereka hasilkan. Daya inovatif yang yang dilakukan pengrajin gerabah yaitu menginovasi jenis gerabah yang mereka hasilkan untuk tampil lebih unik dan bagus dari gerabah yang dihasilkan daerah lain, Sehingga antara pengrajin dari Kecamatan Besuk dengan pengrajin gerabah daerah lainnya mempunyai ciri tersendiri dalam produk yang dihasilkan.
\end{abstract}

Kata Kunci: kerja keras, kreativitas, daya inovatif dan pengrajin gerabah

\section{PENDAHULUAN}

Beragam sektor ekonomi informal berada di Kabupaten Probolinggo, salah satunya ialah sebagai pengrajin gerabah yang dapat menghasilkan berbagai jenis gerabah seperti peralatan dapur, cobek, tungku, souvenir, pot, guci dan lainnya. Pengrajin gerabah ini dapat dijumpai di Kecamatan Besuk. Keputusan mereka dalam memilih bidang ini telah berlangsung sejak lama, dimana bahan baku gerabah ini berasal dari tanah liat yang bisa didapat dari daerah kecamatan Besuk. Tanah liat ini tanpa diolah khusus sudah memenuhi syarat sebagai bahan baku gerabah. Pekerjaan ini efektif digeluti masyarakat kecamatan Besuk sebagai tempat mata pencaharian yang hasilnya dapat memenuhi kebutuhan sehari-hari. Harga jual gerabahnya yang relatif murah dapat memenuhi kebutuhan konsumen yang berpenghasilan rendah.

Perkembangan usaha yang sejenis dan kompetitif di Jawa Timur, mendorong pengrajin gerabah di kecamatan Besuk untuk berpikir dan mengembangkan daya inovasinya. Saat ini kerajinan gerabah di kecamatan Besuk sudah mulai menembus pasar nasional dan internasional. Keberhasilan kerajinan gerabah kecamatan Besuk dalam pemasarannya ditunjukkan dengan jumlah wilayah pemasaran yang sudah menjangkau manca negara yaitu wilayah Eropa meliputi Australia, Swedia, dan Jerman.

Lingkungan masyarakat merupakan salah satu faktor kuat yang mempengaruhi pembentukan karakter usaha seseorang. Sesuai dengan pendapat Agustina (2006:11) menyatakan bahwa "ada pengaruh faktor lingkungan terhadap perilaku wirausaha". Ini erat kaitannya dengan proses pendidikan yang berlangsung dilingkungan tersebut. Lingkungan tempat tinggal memberikan pengarahan dan 
penanaman sikap kewirausahaan. Penanaman sikap mental dalam lingkungan masyarakat, bentuk dan pola tergantung dari kebiasaan yang berkembang dari kebiasaan masyarakat itu sendiri. Diketahui bahwa masyarakat kecamatan Besuk secara turun menurun menekuni usaha kerajian gerabah. Keadaan ini memberikan dampak pada pembentukan sikap dan perilaku kewirausahaan secara alami oleh masyarakat kecamatan Besuk karena mereka sudah mengenal dunia kewirausahaan dibidang kerajian gerabah sejak masih kecil.

Pada umumnya pengrajin gerabah mempunyai perilaku wirausaha seperti dipaparkan Kasali (2013:7-8) diantaranya (1) disiplin, (2) kerja keras, (3) komitmen tinggi, (4) kreatif, (5) inovatif, (6) mandiri, (7) realistis, (8) jujur, (9) prestatif. Pendapat seperti ini sangat mendukung bahwa untuk menjadi pengrajin gerabah diperlukan keterampilan khusus dan harus memiliki karakter dalam berwirausaha untuk menunjang keberhasilannya untuk menjadi pengrajin gerabah.

Observasi yang dilakukan peneliti terhadap pengrajin gerabah di kecamatan Besuk bahwa para pengrajin gerabah mempunyai perilaku kerja keras, kreativitas, dan daya inovasi yang berbeda dalam menghasilkan berbagai jenis dan bentuk gerabah. Perilaku kerja keras pengrajin gerabah di kecamatan Besuk terlihat dari bagaimana mereka melakukan aktifitas sehari - hari dalam menjalankan usahanya tersebut, yaitu Setiap hari menggunakan ketelatenan dalam mengerjakan setiap detail gerabah yang di produksi. Intensitas waktu kerja yang digunakan dalam mengerjakan pembuatan gerabah dilakukan dalam rentang waktu relative lama, semakin lama waktu kerja maka semakin banyak pula jumlah gerabah yang dihasilkan. Hal ini berpengaruh terhadap pencapaian omset yang mereka dapatkan setiap bulan dari hasil penjualan gerabah, hal ini sesuai dengan yang dipaparkan Suherman (2012:108) Sikap kerja keras harus dimiliki oleh seorang wirausahawan. Dalam hal ini, unsur disiplin memainkan peranan penting, sebab bagaimana orang mau bekerja keras jika disiplin tidak ada. Dia harus mengatur waktu, sesuai irama kehidupannya, bangun pagi, siapa siap untuk kerja, mulai kerja, istirahat (tidak terlalu lama), dan setusnya sampai malam tiba.

Menurut Agustina (38:2015) Inovasi adalah kemampuan untuk menerapkan solusi kreatif terhadap masalah dan peluang untuk meningkatkan dan memperkaya kehidupan masyarakat. Daya inovatif yang muncul pada pengrajin gerabah kecamatan Besuk tergambar pada bagaimana mereka menginovasi jenis gerabah yang mereka hasilkan untuk tampil lebih unik dan bagus dari gerabah yang dihasilkan daerah lain. Sehingga antara pengrajin dari kecamatan Besuk dengan pengrajin gerabah daerah lainnya mempunyai ciri tersendiri dalam produk yang dihasilkan. Selain itu, pengembangan wilayah penjualan juga merupakan bentuk daya inovatif yang muncul dari diri pengrajin gerabah kecamatan Besuk.

Berdasarkan uraian latar belakang diatas, peneliti tertarik melakukan penelitian mengenai perilaku kewirausahaan dengan mengambil 3 karakter wirausaha yakni perilaku kerja keras, kreativitas dan daya inovatif. Dimana 3 karakter tersebut sangat berkaitan erat dalam menjalankan usaha sebagai seorang pengrajin gerabah. Peneliti melakukan penelitian dengan judul "Perilaku Kewirausahaan Pengrajin Gerabah di Kecamatan Besuk Kabupaten Probolingo." Permasalahan yang akan dikaji adalah bagaimana perilaku kewirausahaan pengrajin gerabah di Kecamatan Besuk Kabupaten Probolinggo agar dapat bertahan dan berkembang ditengah persaingan pengrajin gerabah lainnya. Sesuai dengan rumusan masalah tujuan yang ingin dicapai adalah untuk mendeskripsikan perilaku kewirausahaan pengrajin gerabah di Kecamatan Besuk kabupaten Probolinggo dalam menjalankan usahanya dibidang kerajinan gerabah.

\section{METODE}

Penelitian ini merupakan deskriptif kualitatif yang bertujuan untuk mendeskripsikan perilaku kewirausahaan pengrajin gerabah di Kecamatan besuk Kabupaten Probolinggo. Penentuan lokasi 
penelitian yaitu menggunakan metode purposive area yaitu Desa Alas Sumur Lor Kecamatan Besuk Kabupaten Probolinggo sedangkan untuk penentuan subjek penelitian menggunakan metode snowball yaitu pengrajin gerabah di Desa Alas Sumur Lor Kecamatan Besuk Kabupaten Probolinggo sebanyak 5 (lima) orang dengan inisial S, Sa, R, W, Sp. Sumber data yang diperoleh berupa data primer, yaitu data dari sumber data yang diperoleh secara langsung dari para narasumber berupa informan penelitian yang terpilih untuk diwawancarai dan diobservasi. dan data sekunder, yaitu data yang diperoleh peneliti dari sumber data secara tidak langsung. Dalam penelitian ini data sekunder sudah tersedia sehingga peneliti tinggal mencari dan mengumpulkan data-data yang diperlukan berupa dokumen atau laporanlaporan. Pada penelitian ini metode pengumpulan data menggunakan metode wawancara mendalam, observasi, dan dokumen. Analisis datanya yang digunakan yaitu reduksi data, display data, dan kesimpulan atau verifikasi.

\section{HASIL DAN PEMBAHASAN}

\section{Hasil Penelitian}

\section{Kerja Keras}

Menjadi Pengrajin gerabah merupakan salah satu pekerjaan utama yang dilakukan masyarakat kecamatan Besuk. Pekerjaan ini dilakukan ketika pagi hari dan berakhir sore hari yaitu dari pukul 06.00 pagi hingga pukul 15.00 sore, jika ada pesanan, pengrajin gerabah juga harus melakukan lembur kerja, waktu kerja bisa hingga pukul 18.00. Hal ini dilakukan agar gerabah yang dihasilkan dapat mencapai kuantitas dan kualitas yang tinggi. Pembuatan gerabah harus melalui proses panjang, mulai dari tahapan penjemuran tanah yang akan digunakan sebagai bahan gerabah hingga pada tahapan pembakaran dan pada jenis gerabah tertentu, tahap akhirnya adalah pengecatan (biasanya gerabah ini pesanan pembeli). Proses demi proses harus dilakukan dengan kehati hatian, karena setiap tahapan berpengaruh dengan tahapan berikutnya. Kerja keras pengrajin gerabah desa alas Sumur Lor tergambar pada disiplin kerja yang dilakukan, yaitu setiap proses atau tahap pembuatan gerabah harus dilakukan sesuai waktu yang dijadwalkan. Proses pembuatan gerabah memerlukan manajemen waktu dan tenaga sehingga kerja sama antar personal pengrajin harus dilakukan, sehingga tepat pada waktunya pengiriman atau penjualan, gerabah sudah siap dipasarkan Hal ini di ungkapkan subjek yang menyatakan:

"Kalau gerabah sudah siap dibakar, harus segera dibakar, jangan sampe di tunda tunda, soalnya kalo ditunda nanti kerjaan jadi numpuk. Jadi meskipun capek harus tetap bakar gerabah" (Sp, 55th)

Kemauan yang keras untuk mencapai tujuan mengacu pada keseriusan pengrajin gerabah untuk mengembangkan dan memperhatankan usaha yang ditekuni. Sikap ini diterapkan oleh salah satu subjek dalam mengelola usaha gerabahnya.

"Dulu sebelum usaha sebesar ini, saya bikin gerabah sendiri, tempatnya bikin di emperan ruman. Prinsipnya kalau mau sukses ya usaha yang sungguh sungguh, saya telateni, saya rawat sungguh - sungguh, pokoknya harus sungguh sungguh. Mangkanya sekarang bisa punya bangunan buat bikin gerabah sendiri " (S, 40th)

Kreativitas dan Daya Inovatif

Kreativitas dan Daya inovatif yang dimiliki pengrajin gerabah di Kecamatan Besuk ini terlihat dari bagaimana para pengrajin gerabah terus melakukan inovasi dalam mengembangkan gerabah yang di produksinya. Jenis gerabah yang dihasilkan pengrajin gerabah desa Alas Sumur Lor juga beragam, dari cobek hingga vas bunga dan guci yang dilapisi cat. Bentuknya juga berbeda dengan gerabah gerabah yang dihasilkan di daerah jawa timur lainnya. Perbedaan bentukdan model sengaja dilakukan agar memiliki ciri khas tersendiri, yaitu warna dari gerabah yang dihasilkan berwarna merah Seperti yang diungkapkan oleh Subjek yang menyatakan : 
"Disini cobeknya berbeda, dibawahnya dan pinggirannya ada lapisnya, kalo cobek dari madura gundulan, jadi kalo barengan bisa dibedakan, selain itu gerabah yang kami hasilkan juga berwarna merah." (Sa, 41th).

Mayoritas jenis gerabah yang diproduksi adalah cobek, pemilihan jenis gerabah ini tidak serta merta tanpa analisis, tapi pemilihan jenis gerabah ini dipilih karena jumlah pembeli terbanyak dari kerajian gerabah membeli gerabah jenis cobek. Hampir setiap rumah di Indonesia pasti menggunakan cobek sebagai salah satu peralatan dapur, sehingga pada gerabah jenis ini diminati oleh pembeli. Untuk menghasilkan produk yang lebih kompetitif pengrajin gerabah di Kecatan Besuk melakukan finishing pengecatan dengan cat kusus atau di glasir, sehingga terlihat indah dan menarik. Glasir memberi efek mengkilat pada gerabah, sehingga unsur mewah pada gerabah akan terlihat. Proses glasir dilakukan setelah gerabah di bakar. Proses glasir harus dilakuakn berlahan agar hasilnya rapi.

"Kalau ada pesanan tertentu, kami menggunakn glasir, jadi mengkilat seperti keramik, meskipun harganya jauh lebih mahal, tapi pembeli mau membeli, karena gerabahnya terlihat mewah" (W, 36th)

Banyaknya jenis gerabah yang sudah di produksi pengrajin Gerabah Desa Alas Sumur Lor tidak menjadikan pengrajin berhenti berinovasi, keinginannya untuk terus mengembangkan dan menciptakan bentuk baru terus dicoba. Usaha untuk direalisasikanya dilakukan dengan terus mengikuti pelatihan tentang gerabah maupun dengan cara uji coba sendiri. Keinginan kedepan yang ingin pengrajin lakukan adalah seperti membuat meja dan kursi dari gerabah, dengan finishing yang indah seperti yang terbuat dari kayu. Seiring perkembangan kemajuan alat elektronik, pengrajin gerabah kecamatan Besuk memiliki ide yang ingin dikembangkan, yaitu menciptakan alat elektronik dari bahan dasar gerabah, karena selama ini alat elektronik hanya berbahan dasar dari besi, alumunium, dll, selain itu selama ini belum ada yang menciptakan alat elektronik dan menjual alat elektronik dari bahan dasar gerabah, sehingga diharapkan dengan ide baru ini, akan membuka pasar gerabah baru. Seperti yang diungkapkan oleh Subjek yang menyatakan:

"impian saya sekarang ingin membuat alat elektronik dari bahan dasar gerabah, misalkan bikin magic com. Kan selama ini belum ada yang menciptakan, jadi nanti sudah dibuat pasti banyak yang penasaran, jadi mereka pasti ingin nyobain, dan mereka akan beli" ( $R$, 40th)

Berdasarkan paparan diatas dapat disimpulkan pengrajin gerabah melakukan kreativitas dan daya inovatif dengan menciptakan gerabah yang memiliki ciri khas tersendiri, yaitu warna gerabah merah, memiliki garis tepian, dan cat yang digunakan adalah pernis agar kenaturalan gerabah bisa terjaga.

\section{Pembahasan}

Berdasarkan penelitian yang telah dilakukan, maka dapat diketahui bahwa pengrajin gerabah di Desa Alas Sumur Lor memiliki perilaku kewirausahaan dalam menjalankan usahanya sehingga usaha kerajinan gerabah bisa bertahan di tengah persaingan pasar. Perilaku yang dimiliki pengrajin gerabah di Desa Alas Sumur Lor yaitu kerja keras dan daya inovatif. Hal ini sesuai dengan yang dikemukakan oleh Daryanto (2013:7) yang menyatakan bahwa karakter wirausaha adalah ciri, watak, sifat, tingkah laku yang khas dari wirausahawan yang membedakan dengan orang lain, salah satunya inovatif dan kerja keras.

Perilaku kerja keras yang dilakukan pengrajin gerabah adalah memanfaatkan waktu semaksimal mungkin untuk membuat gerabah dengan jumlah yang banyak, hal ini terlihat dari pengrajin gerabah menggunakan waktu kerja pada pukul 06.00 pagi hingga pukul 15.00 sore, sedangkan jika ada pesanan dari pembeli mereka juga harus melakukan lemburan. Lemburan kerja selesai pada pukul 18.00. fakta tersebut relevan dengan Agustina (2013:7) Kerja keras adalah kerja 
maksimal tidak kenal lelah, semangat kerja tinggi, tidak membuang buang waktu untuk segera menyelesaikan pekerjaan dengan baik dan cepat, etos kerja tinggi.

Menjaga ketepatan waktu produksi merupakan hal pertama yang dilakukan pengrajin gerabah di Desa Alas Sumur Lor untuk tetap bisa menciptak kuantitas gerabah yang tinggi dengan kualitas bagus. Mereka memaksimalkan semua potensi, termasuk dengan menambah jumlah pekerja, yang awalnya dilakukan seorang diri, selanjutnya merekrut tetangga untuk dijadikan karyawan, selain Memperkerjakan tetangga untuk membantu menyelesaikan pembuatan gerabah, pengrajin gerabah di Desa Alas Sumur Lor juga memanfaatkan anggota keluarga untuk membantu, seperti yang dilakukans subjek 1. Subjek 1 mengajak menantunya untuk membantu proses pembuatan gerabah, meskipun di bantu anggota keluarga sendiri, subjek 1 juga memberi upah kepada menantunya sebagai bentuk keprofesionalan usaha. proses pembutan gerabah yang tidak hanya dilakukan sendiri, namun dibantu karyawan maupun anggota keluarga, relevan dengan pendapat Daryanto (2013:7) manfaat kewirausahaan adalah menampung tenaga kerja sehingga dapat mengurangi pengangguran. Kerja keras untuk menjaga ketepatan waktu agar pada deadline pengiriman gerabah bisa tepat waktu juga memiliki manfaat sebagai sarana daya tampung tenaga kerja agar pengangguran di desa tersebut bisa berkurang, dan pendapatan masyarakat di Desa Alas Sumur Lor meningkat.

Peluang yang dilakukan untuk meningkatkan inovasi gerabah adalah dengan mengikuti berbagai pelatihan mengenai pengembangan jenis gerabah hingga pengelolahan lahan. Pelatihan pelatihan tersebut dapat menambah wawasan pengrajin gerabah untuk meningkatkan kualitas gerabah yang dihasilkan, sehingga jumlah penjualan meningkat, yang berakibat pada tingginya pula omset yang dicapai. Pelatihan yang diikuti oleh pengrajin gerabah desa Alas Sumur Lor yang didukung dan didanai langsung dinas perdagangan dan perindustrian kabupaten probolinggo sudah dilakukan diberbagai daerah, yaitu di antaranya Jogja, Malang, Surabaya, dan Probolinggo.

Menurut Southon ( 38:2015) Inovasi adalah kemampuan untuk menerapkan solusi kreatif terhadap masalah dan peluang untuk meningkatkan dan memperkaya kehidupan masyarakat. Teori tersebut relevan dengan kedaan usaha yang dilakukan pengrajin gerabah di desa alas sumur Lor, dimana pengrajin gerabah memanfaatkan peluang yang diberikan pemerintah untuk melakukan pelatihan agar kemampuan dalam pembuatan gerabah meningkat dan bisa memunculkan inovasi inovasi baru dalam mengembangkan usaha gerabah yang digeluti.

Salah satu aspek terpenting dari sebuah usaha adalah pemasaran. Penjualan gerabah kecamatan Besuk meliputi berbagai daerah di Indonesia, yaitu antaranya Gresik, Jember, Kota Probolinggo, Surabaya, Banyuwangi, Bondowoso, Situbondo, Pasuruan, dan Madura. Penjulan di Luar Negeri Sudah meliputi Negara negara eropa, yaitu Australia, Swedia dan Jerman. Hasil gerabah dari Desa Alas Sumur Lor bisa terjual diberbagai daerah karena memiliki keunikan dan ciri khas tersendiri, yaitu warnanya merah, dan setiap gerabah yang di produksi memiliki garis tepian duduk. Pembeli gerabah juga bisa memesan grabah yang diinginkan sesuai jenis dan motif yang diinginkan, dengan demikian daya inovatif pengrajin gerabah di desa alas sumur Lor juga dituntun lebih, karena harus memproduksi gerabah sesuai permintaan pembeli. Gerabah pesanan biasanya hingga pada finishing pengecatan yaitu tidak hanya berhenti pada proses pembakaran agar hasilnya bagus, dalam pengecatan pun juga memiliki ciri khas tersendiri, yaitu cat yang digunakan menggunakan cat lamir. Keadaan tersebut relevan dengan teori yang di ungkapkan Suryana (2004:165) Inovasi yang sukses adalah yang sederhana dan terfokus. Ia harus terarah secara spesifik, jelas dan memiliki desain yang dapat diterapkan. Inovasi yang dibutuhkan pengrajin gerabah adalah kemampuan wirausahan dalam menambahkan nilai guna/nilai manfaat terhadap suatu produk dan menjaga mutu produk dengan memperhatikan "market oriented" atau yang sedang laku dipasaran. Bertambahnya nilai guna atau 
manfaat pada sebuah produk maka meningkat pula daya jual produk tersebut dimata konsumen, karena adanya peningkatan nilai ekonomis bagi produk tersebut untuk konsumen.

Seorang wirausaha juga selalu mencari cara baru untuk meningkatkan produksi secara efesien. Berbagi gagasan baru yang ingin dilakukan pengrajin gerabah di Desa Alas Sumur Lor sudah mulai terencanakan, keinginan keinginan terkait perkembangan produksi sudah tergambarkan. Banyak inovasi baru yang kedepannya ingin pengrajin lakukan yaitu seperti yang diungkapkan salah satu subjek bahwa produk inovasi baru yang sangat ingin dia ciptakan adalah membuat meja dan kursi dari gerabah, karena di Jawa Timur belum ada sentra kerajian yang menciptakan maupun yang memasarkan meja dan kursi dari gerabah. keinginan mendalam untuk berinovasi pada produk gerabah yang dicipkatakn juga di ungkapkan oleh subjek lain bahwa subjek tersebut ingin menciptakan alat elektronik yang terbuat dari gerabah, ide tersebut muncul karena selama ini alat elektronik hanya berbahan bahan dasar dari besi, alumunium, dll, namun belum ada yang menciptakan dari gerabah. Keadaan tersebut relevan dengan teori yang diungkapkan Suryana (2013: 8) Inovatif adalah membuat terobosan baru, karena adanya invensi (penemuan baru). Secara umum berbagai ide baru dapat terus bermunculan dari pengerajin di kecamatan Besuk dengan meningkatnya pengetahuan mengenai produksi gerabah

\section{PENUTUP}

\section{Kesimpulan}

Berdasarkan hasil penelitian dan pengamatan secara langsung terhadap subjek penelitian ditemukan fakta, bahwa pengrajin gerabah di Kecamatan Besuk menerapkan perilaku kewirausahaan untuk menjalankan usahanya. Adapun alasan peneliti menyatakan hal demikian adalah karena subjek penelitian memiliki sikap sikap yang menjadi indikator perilaku kewirausahaan. Hasil penelitian menyatakan terdapat 3 indikator sikap kewirausahaan yang mampu diwujudkan oleh para pengrajin gerabah di Desa Alas Sumur Lor Kecamatan Besuk Kabupaten Probolinggo, yaitu memiliki perilaku kerja keras, kreativitas dan daya inovatif. Perilaku kerja keras yang dilakukan pengrajin gerabah di kecamatan Besuk Kabupaten Probolinggo, yaitu melalui peoptimalan potensi tenaga dengan setiap harinya menggunakan waktu yang relatif lama dalam membuat gerabah, selain itu pengrajin gerabah juga harus menghasilkan jumlah tertentu dalam kurun waktu tertentu agar gerabah yang dihasilkan bisa segera di jual untuk mencapai target jual yang ingin dicapai pengrajin gerabah. Kreativitas adalah kemampuan melahirkan gagasan - gagasan baru atau penemuan - penemuan baru. Kreativitas yang dilakukan pengrajin gerabah yaitu dengan menentukan jenis barang yang akan mereka hasilkan melalui usahanya tersebut sehingga barang yang dihasilakan dapat diterima dipasaran. Daya inovatif adalah kemampuan unutuk menciptapkan proses atau hasil pengembangan. Daya inovatif yang dimiliki pengrajin gerabah di kecamatan Besuk Kabupaten Proolinggo yaitu terlihat dari pengrajin gerabah yang melakukan inovasi terhadap gerabah yang dihasilkan yaitu melalui cara, jenis, bentuk yang dihasilkan serta menciptakan pelanggan dan pasar baru yang akan dijangkau dalam penjualan gerabah.

\section{Saran}

Berdasarkan kesimpulan dari penelitian ini maka peneliti memberikan saran sebagai berikut: Para pengrajin gerabah hendaknya dapat menggunakan perilaku kewirausahaan yang mereka miliki sebagai semangat untuk mewujudkan harapan yang mereka cita - citakan dalam mengembangkan sentra usaha gerabah mereka. Aparat desa diharapkan bisa bekerja sama dan berkonsolidasi untuk mengembangkan sentra kerajian gerabah sehingga ide ide baru terkait jenis gerabah, pasar, dan alat baru berteknologi lebih modern yang ingin dipergunakan pengrajin gerabah bisa segera terealisasi. 


\section{DAFTAR BACAAN}

Agustina, Tri Siwi. 2015. Kewirausahaan. Jakarta: Mitra Wacana Media.

Daryanto dan Cahyono Aris, D. 2013. Kewirausahaan. Yogyakarta: Gava Media.

Kasali, Rhenald, dkk. 2010. Kewirausahaan. Bandung: PT Mizan Publika.

Southon, Mike. 2005. Menjadi Pengusaha. Jakarta: PT Garmedia Pustaka Utama.

Suherman, Ema. 2012. Kiat Sukses Membangun SDM Indonesia melalui Pendidikan dan Pelatihan Enterpreneurship. Bandung: Alfabeta CV.

Suryana. 2003. Kewirausahaan. Jakarta: Salemba Empat. 